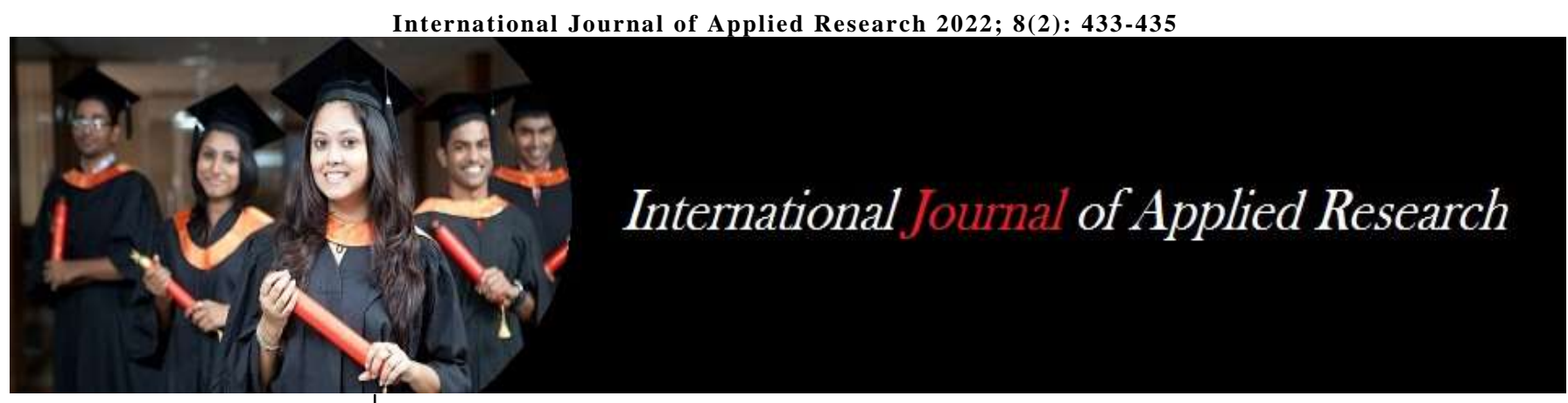

ISSN Print: 2394-7500

ISSN Online: 2394-5869

Impact Factor: 8.4

IJAR 2022; 8(2): 433-435

www.allresearchjournal.com

Received: 22-12-2021

Accepted: 24-01-2022

Manjunatha B

Assistant Professor,

Government First Grade

College, Gauribidanur,

Karnataka, India
Corresponding Author:

Manjunatha B

Assistant Professor,

Government First Grade

College, Gauribidanur,

Karnataka, India

\section{The role of English literature in re-constructing society}

\section{Manjunatha B}

DOI: $\underline{\text { https://doi.org/10.22271/allresearch.2022.v8.i2f.9481 }}$

\section{Abstract}

Literature is the mirror of society and a form of art. The study of English literature allows people to develop new ideas and new ways of thinking about the world. It can help individual to present themselves as educated members of society, it involves the contemplation of the essence of society and how individuals work within the confines of society's structure. Understanding how literature motivates the individual and how it is reflexive of the individual's society is something that ought to be given more attention and consideration. It is capable of bringing about different emotions and a general sense of "Spiritual" well-being. Literature is also crucial to learn stylistic and artistic conventions for communication and writing. Studying literature is an enriching, eye-opening experience and helps in construction of valuable society.

Keywords: Literature, society, contemplation, essence, spiritual well-being, stylistic, artistic, communication, convention, enriching

\section{Introduction}

Literature is a topic that is interesting and has an overwhelming approach in this $21 \mathrm{st}$ century. It is the only means to connect the world literature with each other. Studying literature allows us to understand the philosophical movements and ideas that permeated a particular culture at particular time. Literature has had a major impact on the development of society. It has shaped civilizations, changed political systems and exposed injustice. Literature gives us a detailed preview of human experiences, allowing us to connect on basic levels of desire and emotion. What is literature and its constructive role in the lives of individuals and society?

The quest to discover a definition for "literature" is a road that is much travelled, though the point of arrival, if ever reached, is seldom satisfactory. Most attempted definitions are broad and vague, and they inevitably change over time. In fact, the only thing that is certain about defining literature is that the definition will change. Concepts of what is literature change over time as well. What may be considered ordinary and not worthy of comment in one-time period may be considered literary genius in another. Initial reviews of Emily Bronte's Wuthering Heights in 1847 were less than spectacular, however, Wuthering Heights is now considered one of the greatest literary achievements of all time. The same can be said for Herman Melville's Moby-Dick (1851).

\section{What is Literature?}

Generally, most people have their own ideas of what literature is. When enrolling in a literary course at university, you expect that everything on the reading list will be "literature". Similarly, you might expect everything by a known author to be literature, even though the quality of that author's work may vary from publication to publication. Perhaps you get an idea just from looking at the cover design on a book whether it is "literary" or "pulp". Literature then, is a form of demarcation, however fuzzy, based on the premise that all texts are not created equal. Some have or are given more value than others.

Most forays into the question of "what is literature" go into how literature works with the reader, rather than how the author set about writing it. 
It is the reception, rather than the writing, which is the object of enquiry. Largely, what we call "literature" is often a subjective value judgment, and naturally, value judgments, like literary tastes, will change.

Etymologically, literature has to do with letters, the written as opposed to the spoken word, though not everything that is written down is literature. As a classification, it doesn't really have any firm boundary lines. The poet Shelley wanted to include some legislative statutes of parliaments under poetry because they created order and harmony out of disorder. There is recurring agreement amongst theorists though that for a work to be called literature must display excellence in form and style. Something may also be literary by association - that is, because V.S. Naipaul is a literary figure through his novels, his private letters are passed as literature as well.

There is also general agreement that literature foregrounds language, and uses it in artistic ways. Terry Eagleton goes some way towards a definition of literature and its relationship to language: "Literature transforms and intensifies ordinary language, deviates systematically from everyday speech". Just as architecture is the art form that arises out of the human ability to create buildings, literature is the art form that arises out of the human ability to create language.

The common definition of literature, particularly for university courses, is that it covers the major genres of poetry, drama, and novel/fiction. The term also implies literary quality and distinction. This is a fairly basic view of literature because, as mentioned in the introduction, the meaning of the term has undergone changes, and will no doubt continue to do so. Most contemporary literary histories show a shift from the belles-lettres tradition, which was concerned with finding beauty, an elevated use of language, emotional effects and moral sentiments before something could be called literature.

The three main ways of approaching a definition of literature are relativism, subjectivism and agnosticism. With relativism, there are no value distinctions in literature; anything may be called good literature. Subjectivism, as the term implies, means that all theories of literary value are subjective, and that literary evaluation is a purely personal matter. Agnosticism follows from subjectivism, though it argues that though there may be real distinctions in literary value, our subjective value systems prevent us from knowing anything about the real values.

By the 1980s, there was a sense of inclusiveness (and relativism) in what was termed literary that ran alongside the inclusiveness of multiculturalism - anything could be literature, and attempts were made to dismantle distinctions between high and low culture. Letters, diaries, reports, petitions, journals and essays as well as the traditional genres of novel, short story, poem and play can be included as literature. In universities, literature began to be studied for issues and themes, and works were valued for their ideas and engagement with the world as much as for their aesthetic qualities. These standards are also applied to nonfiction, such as auto/biography and philosophy. The most recent amendment to what constitutes literature is the inclusion of oral narratives. This inclusion hasn't been without debate. There is some argument that the written word lends itself more easily to analysis, while the flip side is that oral narratives are a legitimate part of a culture's literary capital.
Definitions of literature change because they describe and clarify a reality, they do not create the reality they describe. Or it may be that definitions tell us what we ought to think literature should be. At a dinner party you would be swiftly corrected if you referred to Mills \& Boon as literature. This might occur for two reasons: the common perception of literature as described by current definitions doesn't include mass-market romance novels; or Mills \& Boon might well be literature, but contemporary definitions tell us it shouldn't be.

Does it really matter what "literature" is? Does everyone have to agree? Because there is no hard and fast definition of literature, perhaps it is more beneficial to seek an analysis instead. What purposes does literature serve? What distinguishes literature from non-literary works? What makes us treat something as literature? How do we know when something is literature? Would it be easier to ask "what isn't literature"?

Literature is as literature does. In exploring ideas about what literature is, it is useful to look at some of the things that literature does. Literature is something that reflects society, makes us think about ourselves and our society, allows us to enjoy language and beauty, it can be didactic, and it reflects on "the human condition". It both reflects ideology and changes ideology, just like it follows generic conventions as well as changing them. It has social and political effects: just ask Salman Rushdie or Vladimir Nabokov. Literature is the creation of another world, a world that we can only see through reading literature

The Role of Literature:

Literature has two roles, an active, engaging role and a passive, reflective role. The active role represents the very action of reading. This role is a significant part of an individual's development. From reading an individual forms ideas and concepts about the world in which they live. These ideas and concepts form together into an ideology of sort. From this ideology stems individual motivation, action, and engagement.

The second role is distinguishable from the first in that it is a thing observed, rather than a thing done. The reflective role of literature is to show society the history of ideologies, of thought and of action. It allows the individual to understand how a society functioned and why it functioned that way. "Literature is thought provoking, it allows us to raise questions and gives us a deeper understanding of issues and situation". Said Judith Caesar.

Caesar emphasized literature's role in allowing its reader to grasp the meaning of human conflict. Literature has had a major impact on the development of society. It has shaped civilizations, changed political systems and exposed injustice. Literature gives us a detailed preview of human experiences, allowing us to connect on basic levels of desire and emotion. However, just as it has constructed societies, the writings and works of certain authors have degraded societies of their most primitive form. Literature enhances ELT through elements such as authentic material, language in use and aesthetic representation of the spoken language, as well as language and cultural enrichment. It is with this last element that literature opens the door that leads to a wider and closer look on the culture where the target language is spoken.

\section{Conclusion}

Of course there are myriad of other influencing factors, such as institutions, communities, and families; literature does 
not exist in a vacuum. It does, however, have a unique function in shaping and teaching society at large. For such a seemingly petty question, it involves the contemplation of the essence of society and how individuals work within the confines of society's structure. Understanding how literature motivates the individual and how it is reflexive of the individual's society is something that ought to be given more attention and consideration.

\section{References}

1. http://politicalcartel.org/2008/12/31/what-is-the-role-ofliterature-in-society/http://gulfnews.com/about-gulfnews/al-nisr-portfolio/notes/articles/literature-is-themirror-of- society-1.86134

2. http://en.m.wikipedia.org/wiki/indian_literature_english _language. http://en.m.wikipededia.org/wiki/literature.

3. Simon Ryan, Delyse Ryan. What is literature", foundation: Fundamentals of literature and drama. Australian Catholic University. Retrieved 9 February 2014.

4. Oxford University Press, rev. ("the standard work on the subject and unlikely to be Surpassed"- Malhotra, 2003), 2001. 